\title{
Comparison of the effects between MPL and JAK2V617F on thrombosis and peripheral blood cell counts in patients with essential thrombocythemia: a meta-analysis
}

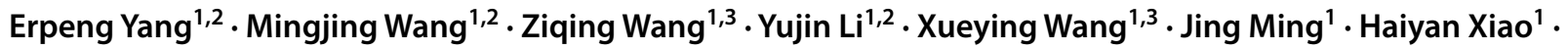 \\ Richeng Quan ${ }^{1} \cdot$ Weiyi Liu ${ }^{1} \cdot$ Xiaomei Hu${ }^{1}$
}

Received: 17 April 2021 / Accepted: 16 July 2021 / Published online: 12 August 2021

(C) The Author(s) 2021

\begin{abstract}
To assess the effects between MPL and JAK2V617F on the thrombosis risk and peripheral blood cell counts in patients with essential thrombocythemia (ET), we identified eligible studies from PubMed, Embase, and the Cochrane Library. Seven studies were ultimately included in this meta-analysis. All studies reported the peripheral blood cell counts of ET patients, and three of them reported the eligible thrombotic events. In comparing the effect of MPL versus JAK2V617F on thrombosis, $1257 \mathrm{ET}$ patients (73 MPL + and $1184 \mathrm{JAK} 2 \mathrm{~V} 617 \mathrm{~F}+$ ) were included. MPL-positive (MPL +) ET patients had a higher risk of thrombosis than JAK2V617F-positive (JAK2V617F +) ET patients [RR=1.80 (1.08-3.01), $P=0.025]$. And 3453 ET patients (138 MPL + and $3315 \mathrm{JAK} 2 \mathrm{~V} 617 \mathrm{~F}+)$ were included in the comparison of peripheral blood cell counts. Platelet counts of MPL + ET patients were higher than that of JAK2V617F + ET patients [WMD =81.18 (31.77-130.60), $P=0.001]$. MPL + ET patients had lower hemoglobin [WMD $=-11.66(-14.32$ to -9.00$), P=0.000$ ] and white blood cell counts $[\mathrm{WMD}=-1.01(-1.47$ to -0.56$), P=0.000]$ than JAK2V617F + ET patients. These findings indicate that the MPL mutation is a high-risk factor for thrombosis in ET patients, and it may be rational to include MPL mutation in the revised IPSET as a criterion for thrombosis prediction scores. And given the differences in peripheral blood, it is necessary to further study whether MPL + ET patients differ from JAK2V617F + ET patients in bleeding and survival.
\end{abstract}

Keywords MPL · JAK2V617F · Thrombosis · Blood cells · Essential thrombocythemia · Meta-analysis

\section{Introduction}

Essential thrombocythemia (ET) is a kind of myeloproliferative neoplasms (MPN), characterized by the proliferation of bone marrow megakaryocytes and the increase of peripheral

Erpeng Yang and Mingjing Wang contributed equally to this work

Weiyi Liu

liuweiyi0530@hotmail.com

Xiaomei $\mathrm{Hu}$

huxiaomei_2@163.com

1 Department of Haematology, Xiyuan Hospital of China Academy of Chinese Medical Sciences, No.1 Xiyuan Caochang Road, Haidian District, Beijing 100091, China

2 Graduate School of China Academy of Chinese Medical Sciences, Beijing 100700, China

3 Xiyuan Clinical Medical College of Beijing University of Traditional Chinese Medicine, Beijing 100029, China blood platelet counts. The median overall survival (OS) time for patients with ET is 18 years [1]. The main treatment of ET is to prevent thrombosis, and the incidence of thrombosis in ET is $21 \%$ after diagnosis [1-3]. As the three driver genes of ET, the mutation rates of JAK2V617F, MPL, and CALR are about $60 \%, 3 \%$, and $20 \%$ respectively [4].

The risk of thrombosis and peripheral blood cell counts have important clinical significance to the treatment and prognosis of ET patients. Compared with JAK2V617F + patients, CALR + patients and the triple negative (TN) patients have a lower risk of thrombosis [5-8]. Because of the low frequency of MPL mutation in ET, the risk of thrombosis and the peripheral blood cell counts of MPL + patients have not been clearly defined. It had previously been reported that MPL mutations had a similar effect on thrombotic events compared with JAK2V617F mutations [9]. However, MPL mutations had also been shown to be more likely to promote thrombosis than JAK2V617F mutations in patients with ET [10]. These two studies involved 
a small number of patients, and the results were obviously controversial. Hence, we performed this meta-analysis to compare thrombotic events and peripheral blood cell counts between MPL + and JAK2V617F + ET patients.

\section{Methods}

\section{Protocol registration}

The protocol for this review was registered in advance in the International Prospective Register of Systematic Reviews (PROSPERO registration number, CRD42021241097) [11].

\section{Literature search and search strategy}

We conducted a systematic literature search on PubMed, EMBASE, and the Cochrane Library for potentially relevant studies published from inception to December 31, 2020. The search terms were as follows: "JAK2V617F," "MPL," "essential," "thrombocytosis," "thrombocythemia," and "thrombosis."

\section{Selection criteria}

Only papers meeting all of the following criteria were included: (1) They were published as original articles from inception to 31 December 2020. (2) They diagnosed patients with ET according to criteria of the Polycythemia Vera Study Group (PVSG) or the World Health Organization (WHO) criteria [12-14]. (3) The number of MPL + or JAK2 $2617 \mathrm{~F}+\mathrm{ET}$ patients must all be greater than or equal to 5. (4) They provided data on thrombotic events after diagnosis or peripheral blood cell counts (hemoglobin, white blood cells, and platelets) at diagnosis/enrollment. (5) Multiple reports of a study were considered as one publication and only the most complete article was examined. (6) Review articles, case reports, and conference abstracts were excluded. Two reviewers independently screened the database and identified eligible studies. Disagreements were resolved through discussion.

\section{Data extraction}

Two reviewers (Erpeng Yang and Mingjing Wang) independently reviewed all articles that met the inclusion criteria. The following information was extracted and listed for each eligible study: first author, year, study location, gender, number of people, diagnostic criteria, peripheral blood cell counts, and data on thrombotic events. In this study, thrombotic events after diagnosis and peripheral blood cell counts at diagnosis/enrollment were selected as the results. If the original study only provided the median and range of the patient's peripheral blood cell counts, the meta-analysis could not be completed directly. We would first contact the author and ask whether we could get the raw data. When we finally got no response, we would estimate the mean value and standard deviation by using the median, range, and sample size [15].

\section{Quality assessment}

Two authors (Erpeng Yang and Mingjing Wang) independently assessed the methodological quality of each study by using the Newcastle-Ottawa Quality Assessment Scale (NOS) for cohort studies [16]. Another reviewer (Ziqing Wang) addressed any discrepancies. There are nine items on the scale, which are divided into three categories: selection (four items), comparability (two items), and cohort design outcomes (three items). According to the NOS, the quality of these studies was divided into three types: high (7-9 points), medium (4-6 points), and low (1-3 points).

\section{Statistical analysis}

Stata version 14.0 software (Stata Corp., College Station, TX, USA) was used to calculate the effects of MPL and JAK2V617F mutations on thrombosis and peripheral blood cell counts of ET patients. The number of patients and thrombotic events in each group were used to calculate the relative risks (RRs) and the 95\% confidence intervals $[17,18]$. The number of patients and the peripheral blood counts were used to calculate the weighted mean differences (WMDs) and the 95\% confidence intervals [19]. We assessed the statistical heterogeneity by $Q$-test and $I^{2}$ statistics. When $I^{2}$ was $>50 \%$ or $P<0.10$, the random-effects model results would be used; otherwise, the fixed-effects model results were preferred. Funnel plots, Begg's test, and Egger's test were used to detect publication bias if the final number of included studies was not less than 10 [20-22]. An asymmetric funnel plot or a $P$ value of less than 0.05 for either of the two tests was considered as publication bias. For all the outcomes, a $P$ value of less than 0.05 was considered statistically significant.

\section{Results}

\section{Search results}

A total of 1923 studies were obtained from the initial search, of which 377 were excluded because of duplication. After screening the titles and abstracts of 1546 studies, 60 studies were left for full-text review. Based on the selection criteria, 7 studies were eventually included. The study selection process is shown in Fig. 1. 
Fig. 1 Flow diagram of study selection

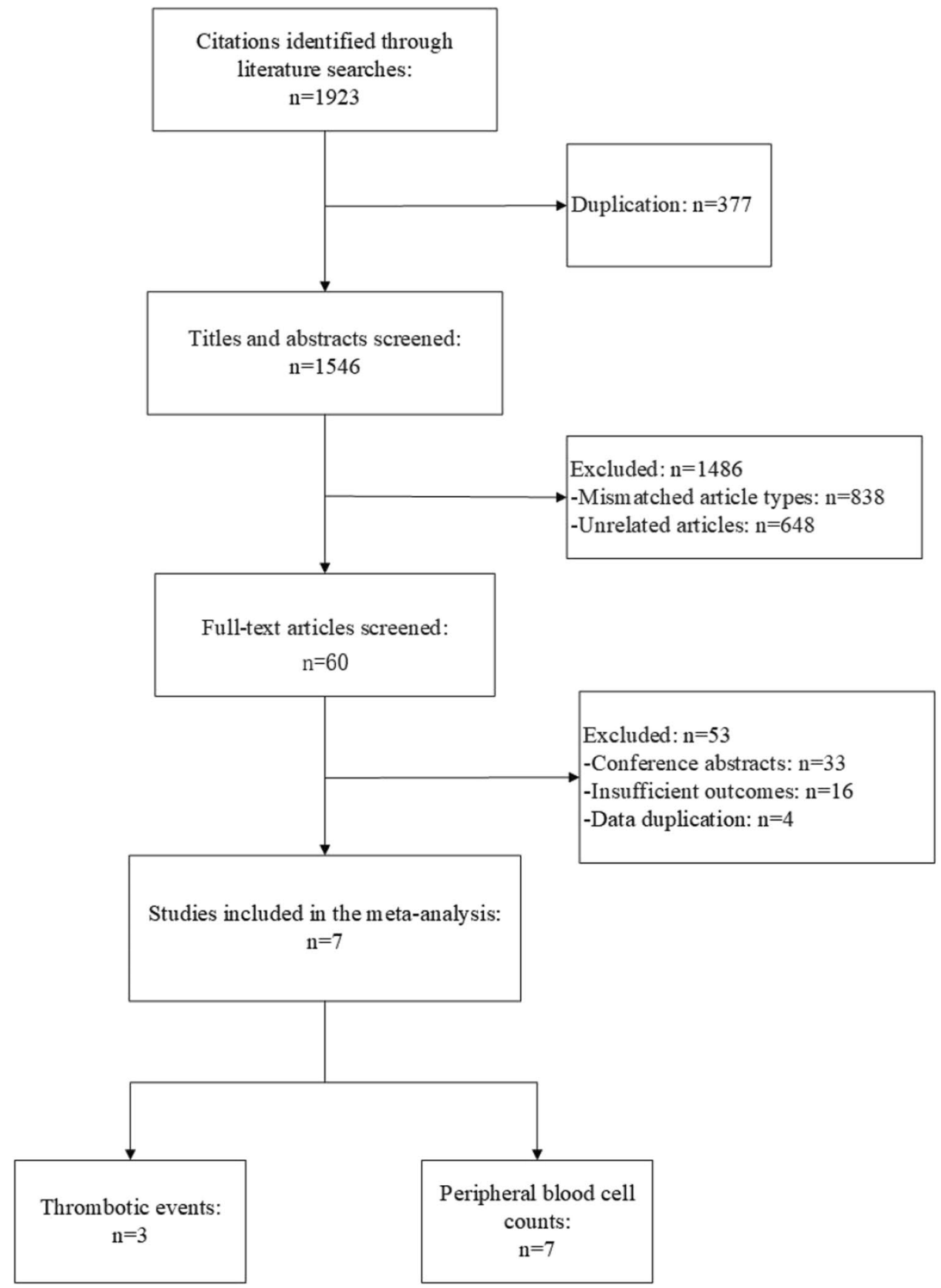

\section{Characteristics of included studies}

The meta-analysis included 5 prospective studies [10,23-26] and 2 retrospective studies [27, 28], including a total of 3453 patients with ET (138 MPL + and $3315 \mathrm{JAK} 2 \mathrm{~V} 617 \mathrm{~F}+)$. There were 3 studies $[10,23,25]$ that included eligible data on thrombotic events after diagnosis. Peripheral blood cell counts were reported in all studies. In these studies, four were from Europe [10, 23, 26, 28], two from China [24, 27], and one from the USA [25]. The characteristics of these studies are reported in Table 1.

\section{Quality assessment of included studies}

The median overall score of NOS outcomes of the included studies was 8 (range 7-9), which indicated that the methodological quality was high (Table 2).

\section{Outcomes of thrombotic events}

As shown in Fig. 2, three studies with 1257 ET patients (73 MPL + and $1184 \mathrm{JAK} 2 \mathrm{~V} 617 \mathrm{~F}+$ ) reported data on thrombosis. Heterogeneity was not statistically significant 


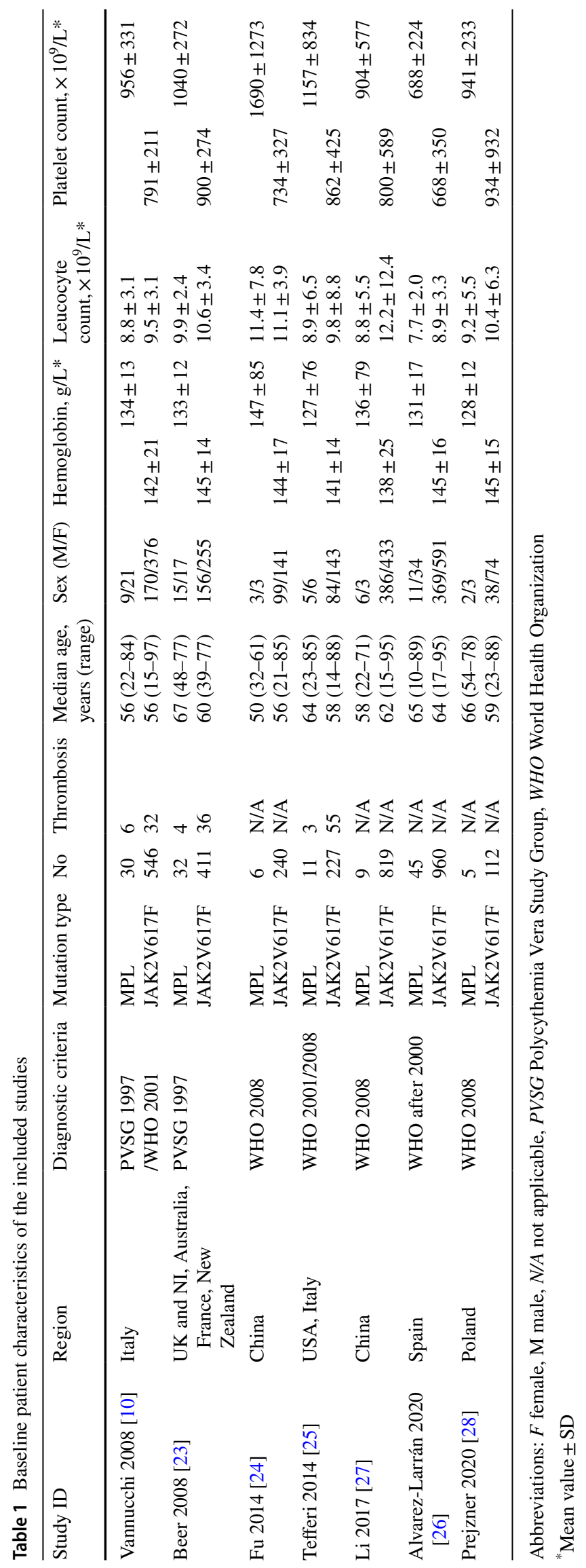


Table 2 Quality assessment of NOS

\begin{tabular}{|c|c|c|c|c|c|c|c|c|c|}
\hline \multirow[t]{2}{*}{ Study ID } & \multicolumn{4}{|l|}{ Selection } & \multirow[t]{2}{*}{ Comparability } & \multicolumn{3}{|l|}{ Outcome } & \multirow[t]{2}{*}{ Score } \\
\hline & $\begin{array}{l}\text { Representative- } \\
\text { ness of exposed } \\
\text { cohort }\end{array}$ & $\begin{array}{l}\text { Selection of } \\
\text { non-exposed } \\
\text { cohort }\end{array}$ & $\begin{array}{l}\text { Ascertain- } \\
\text { ment of } \\
\text { exposure }\end{array}$ & $\begin{array}{l}\text { Outcome not } \\
\text { present at } \\
\text { beginning of } \\
\text { study }\end{array}$ & & $\begin{array}{l}\text { Assessment } \\
\text { of outcome }\end{array}$ & $\begin{array}{l}\text { Follow- } \\
\text { up } \\
\text { length }\end{array}$ & $\begin{array}{l}\text { Follow-up } \\
\text { adequacy }\end{array}$ & \\
\hline $\begin{array}{l}\text { Vannucchi } 2008 \\
\text { [10] }\end{array}$ & $\star$ & $\star$ & $\star$ & $\star$ & $\star$ & $\star$ & $\star$ & $\star$ & 8 \\
\hline Beer 2008 [23] & $\star$ & $\star$ & $\star$ & $\star$ & $\star \star$ & $\star$ & $\star$ & $\star$ & 9 \\
\hline Fu 2014 [24] & $\star$ & $\star$ & $\star$ & $\star$ & $\star$ & $\star$ & $\star$ & $\star$ & 8 \\
\hline $\begin{array}{l}\text { Tefferi } 2014 \\
{[25]}\end{array}$ & $\star$ & $\star$ & $\star$ & $\star$ & $\star \star$ & $\star$ & $\star$ & $\star$ & 9 \\
\hline Li 2014 [27] & $\star$ & $\star$ & $\star$ & - & $\star$ & $\star$ & $\star$ & $\star$ & 7 \\
\hline $\begin{array}{l}\text { Alvarez-Larrán } \\
2020 \text { [26] }\end{array}$ & $\star$ & $\star$ & $\star$ & $\star$ & $\star$ & $\star$ & $\star$ & $\star$ & 8 \\
\hline $\begin{array}{l}\text { Prejzner } 2020 \\
\text { [28] }\end{array}$ & $\star$ & $\star$ & $\star$ & - & $\star$ & $\star$ & $\star$ & $\star$ & 7 \\
\hline
\end{tabular}

Note: A study can be awarded a maximum of one star for each numbered item within the Selection and Outcome categories. A maximum of two stars can be given for Comparability

Fig. 2 Forest plots of the RRs for the risk of thrombosis between MPL + and JAK2V617F+ET patients
Study
ID

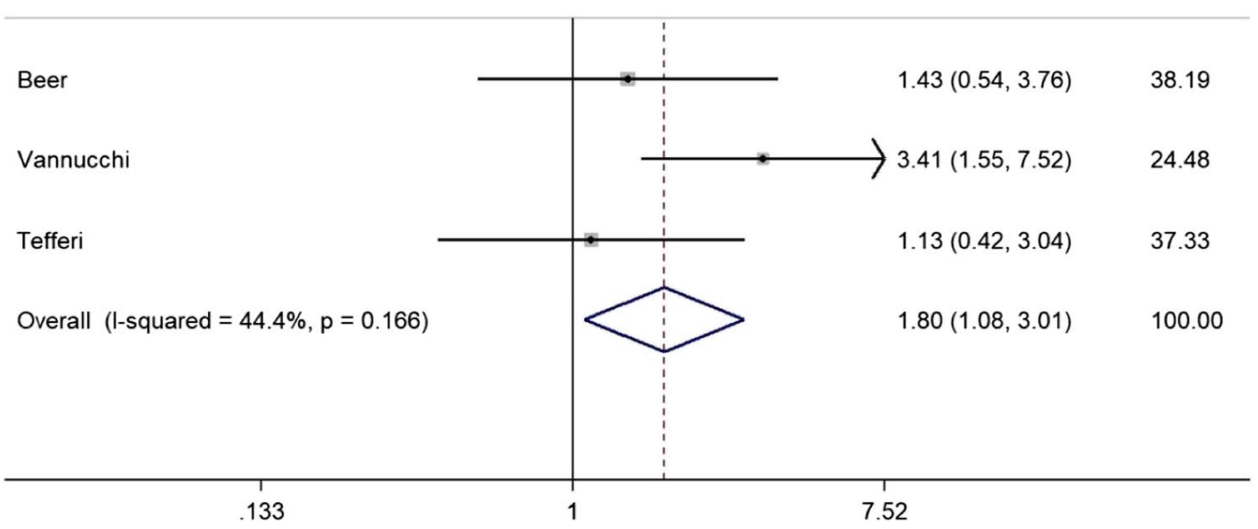

$\left[I^{2}=44.4 \%, P=0.166\right]$. RRs were combined using the Mantel-Haenszel fixed effects model to estimate pooled point estimates and their confidence intervals [18]. In this population, MPL + patients had a higher risk of thrombosis than JAK2V617F + patients [RR $=1.80(1.08-3.01), P=0.025]$.

\section{Outcomes of peripheral blood cell counts}

As shown in Fig. 3A-C, data for peripheral blood cell counts were obtained from 7 studies. There were $3453 \mathrm{ET}$ patients, including $138 \mathrm{MPL}+$ and 3315 JAK2V617F + patients. In this population, MPL + ET patients had lower hemoglobin levels than
JAK2V617F + ET patients [WMD $=-11.66(-14.32$ to -9.00$), P=0.000]$ and the heterogeneity between these studies was not important $\left[I^{2}=0, P=0.654\right]$ [29]. MPL + patients had lower white blood cell counts than JAK2V617F + patients [WMD $=-1.01(-1.47$ to -0.56$)$, $P=0.000]$ and the heterogeneity between studies was not important $\left[I^{2}=0, P=0.822\right]$ [29]. In addition, platelet counts were higher in patients with MPL mutation compared to those with JAK2V617F mutation [WMD $=81.18$ (31.77-130.60), $P=0.001]$, and there was not statistically significant heterogeneity between studies $\left[I^{2}=40.8 \%\right.$, $P=0.119]$. 

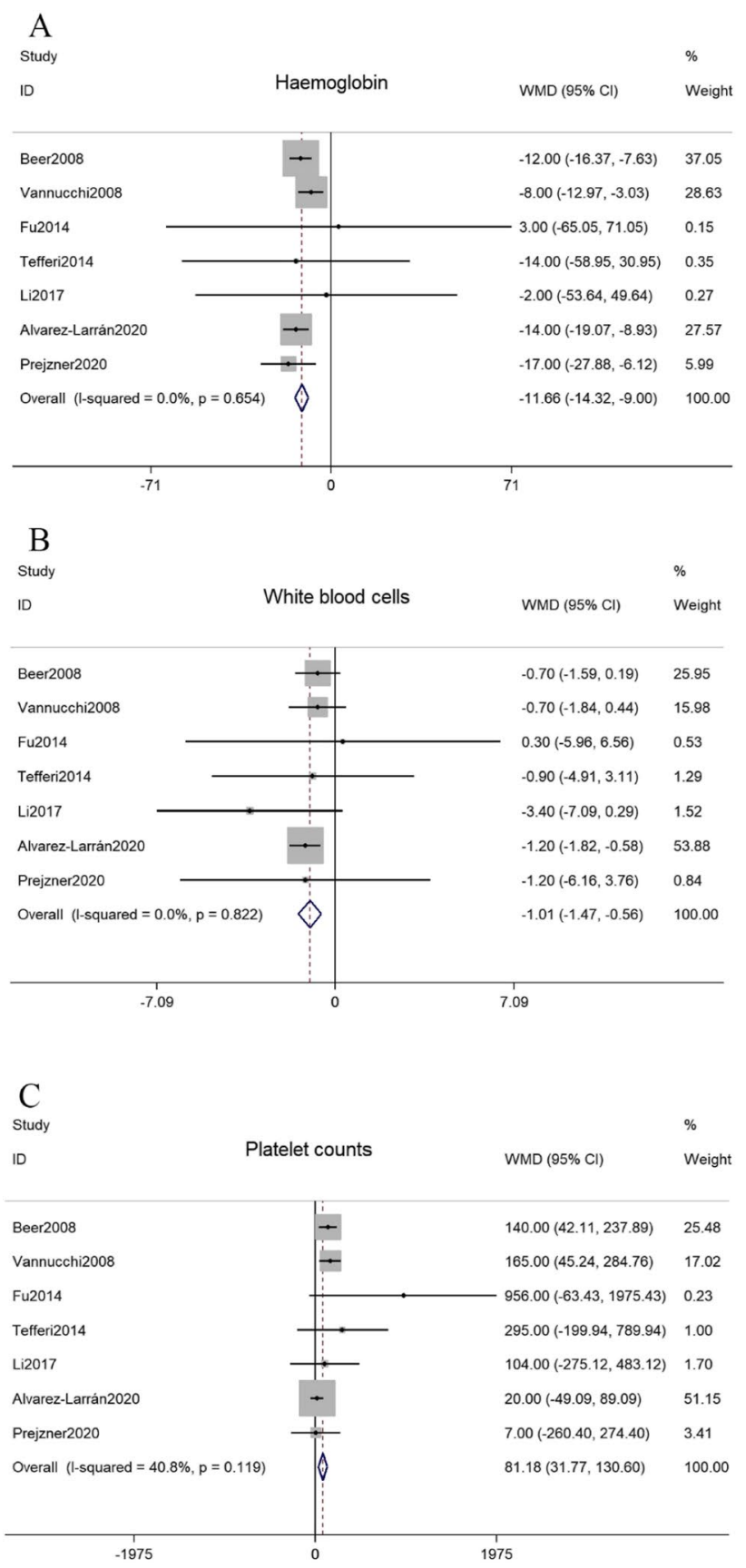

Fig. 3 Forest plots of the WMDs for the peripheral blood cell counts between MPL + and JAK2V617F + ET patients. A for the haemoglobin levels. B for the white blood cell counts. $\mathbf{C}$ for the platelet counts

\section{Discussion}

Thrombotic events severely affect the quality of life and longevity of ET patients. JAK2V617F mutation is an established risk factor for thrombosis [30-33]. However, due to the low mutation rate of MPL in ET patients, there are few reports about the thrombotic events. Many thrombotic events had been reported without indepth follow-up, so there was little mention of thrombotic events after diagnosis in patients with ET [26, 34-36]. The thrombotic events that occurred at the time of diagnosis and after are clearly more relevant to the disease than the thrombotic events prior to the diagnosis of ET. Because the time between actual onset and diagnosis is not clear, thrombotic events of ET patients at diagnosis are less comparable than those after diagnosis. In contrast, patients have a definite follow-up period after diagnosis, so their thrombotic event results can better reflect the actual risk of thrombosis. This meta provided a better understanding of the thrombotic risk and clinical blood cells profiles of MPL +ET patients by comparing them to JAK2V617F+ET patients.

The seven papers included in this research were of high quality. JAK2V617F mutation is an established risk factor for thrombosis [30-33], which has been included in the International Prognostic Score of thrombosis in World Health Organization-essential thrombocythemia (IPSETthrombosis) [37] and the later revised IPSET [38, 39]. This result of this study showed that the MPL mutation promoted thrombosis more than the JAK2V617F mutation. Therefore, it may be rational to include MPL mutation in the revised IPSET as a criterion for thrombosis prediction scores. In this study, platelet counts of MPL + patients were higher than that of JAK2V617F + patients, while white blood cell counts and hemoglobin were lower than in JAK2 V617F + patients, which was consistent with Beer's study [23]. In ET patients, platelet count is closely related to bleeding and other complications, and white blood cell count is closely related to survival prognosis $[4,40]$. Based on the above correlations, it is necessary to further compare the bleeding and survival between MPL + patients and JAK2 +ET patients. It should be noted that some instances of MPL-mutated ET might actually represent prefibrotic primary myelofibrosis (pre-PMF) [41]. There were no statistically significant differences in hemoglobin levels, white blood cell counts, platelet counts, and post-diagnostic thrombosis between MPL +ET patients and those reclassified as pre-PMF from MPL+ET [41]. Therefore, this factor had little impact on the results of this study.

The following are the main limitations of our meta-analysis. The number of included studies was relatively small and the publication bias could not be analyzed. In addition, these studies involving thrombosis were limited to Western populations and lacked patients from multiple regions. In view of the limited number of studies included in the analysis, our meta-analysis results should be confirmed in future studies comparing the effects of MPL mutation with JAK2V617F mutation on thrombosis in ET patients.

\section{Conclusion}

In conclusion, the MPL mutation is a high-risk factor for thrombosis in ET patients, and it may be rational to include MPL mutation in the revised IPSET as a criterion 
for thrombosis prediction scores. And given the differences in peripheral blood, we recommend further studies to determine whether MPL + ET patients differ from JAK2V617F + ET patients in bleeding and survival.

Acknowledgements We thank all of our colleagues who contributed to this meta-analysis.

Funding This study was funded by the National Natural Science Foundation of China (No. 81673821) to Xiaomei Hu, the National Natural Science Foundation of China (No. 81774142) to Haiyan Xiao, and the Special Research Foundation of Central Level Public Scientific Research Institutes (ZZ10-016) to Xiaomei Hu.

\section{Declarations}

Conflict of interest The authors declare no competing interests.

Open Access This article is licensed under a Creative Commons Attribution 4.0 International License, which permits use, sharing, adaptation, distribution and reproduction in any medium or format, as long as you give appropriate credit to the original author(s) and the source, provide a link to the Creative Commons licence, and indicate if changes were made. The images or other third party material in this article are included in the article's Creative Commons licence, unless indicated otherwise in a credit line to the material. If material is not included in the article's Creative Commons licence and your intended use is not permitted by statutory regulation or exceeds the permitted use, you will need to obtain permission directly from the copyright holder. To view a copy of this licence, visit http://creativecommons.org/licenses/by/4.0/.

\section{References}

1. Szuber N, Mudireddy M, Nicolosi M, Penna D, Vallapureddy RR, Lasho TL, Finke C, Begna KH, Elliott MA, Hook CC, Wolanskyj AP, Patnaik MM, Hanson CA, Ketterling RP, Sirhan S, Pardanani A, Gangat N, Busque L, Tefferi A (2019) 3023 Mayo Clinic patients with myeloproliferative neoplasms: risk-stratified comparison of survival and outcomes data among disease subgroups. Mayo Clin Proc 94(4):599-610. https://doi.org/10.1016/j.mayocp. 2018.08.022

2. Girodon F, Bonicelli G, Schaeffer C, Mounier M, Carillo S, Lafon I, Carli PM, Janoray I, Ferrant E, Maynadié M (2009) Significant increase in the apparent incidence of essential thrombocythemia related to new WHO diagnostic criteria: a population-based study. Haematologica 94(6):865-869. https://doi.org/10.3324/haematol. 2008.004234

3. Finazzi G, Carobbio A, Thiele J, Passamonti F, Rumi E, Ruggeri M, Rodeghiero F, Randi ML, Bertozzi I, Vannucchi AM, Antonioli E, Gisslinger H, Buxhofer-Ausch V, Gangat N, Rambaldi A, Tefferi A, Barbui T (2012) Incidence and risk factors for bleeding in 1104 patients with essential thrombocythemia or prefibrotic myelofibrosis diagnosed according to the 2008 WHO criteria. Leukemia 26(4):716-719. https://doi.org/10.1038/leu.2011.258

4. Tefferi A, Pardanani A (2019) Essential thrombocythemia. N Engl J Med 381(22):2135-2144. https://doi.org/10.1056/NEJMcp1816 082

5. Rumi E, Pietra D, Ferretti V, Klampfl T, Harutyunyan AS, Milosevic JD, Them NC, Berg T, Elena C, Casetti IC, Milanesi C, Sant'antonio E, Bellini M, Fugazza E, Renna MC, Boveri E, Astori C, Pascutto C, Kralovics R, Cazzola M (2014) JAK2 or
CALR mutation status defines subtypes of essential thrombocythemia with substantially different clinical course and outcomes. Blood 123(10):1544-1551. https://doi.org/10.1182/ blood-2013-11-539098

6. Rotunno G, Mannarelli C, Guglielmelli P, Pacilli A, Pancrazzi A, Pieri L, Fanelli T, Bosi A, Vannucchi AM (2014) Impact of calreticulin mutations on clinical and hematological phenotype and outcome in essential thrombocythemia. Blood 123(10):15521555. https://doi.org/10.1182/blood-2013-11-538983

7. Palandri F, Latagliata R, Polverelli N, Tieghi A, Crugnola M, Martino B, Perricone M, Breccia M, Ottaviani E, Testoni N, Merli F, Aversa F, Alimena G, Cavo M, Martinelli G, Catani L, Baccarani M, Vianelli N (2015) Mutations and long-term outcome of 217 young patients with essential thrombocythemia or early primary myelofibrosis. Leukemia 29(6):1344-1349. https://doi. org/10.1038/leu.2015.87

8. Gangat N, Wassie EA, Lasho TL, Finke C, Ketterling RP, Hanson CA, Pardanani A, Wolanskyj AP, Maffioli M, Casalone R, Passamonti F, Tefferi A (2015) Mutations and thrombosis in essential thrombocythemia: prognostic interaction with age and thrombosis history. Eur J Haematol 94(1):31-36. https://doi.org/10.1111/ejh. 12389

9. Tefferi A, Vannucchi AM, Barbui T (2018) Essential thrombocythemia treatment algorithm 2018. Blood Cancer J 8(1):2. https://doi.org/10.1038/s41408-017-0041-8

10. Vannucchi AM, Antonioli E, Guglielmelli P, Pancrazzi A, Guerini V, Barosi G, Ruggeri M, Specchia G, Lo-Coco F, Delaini F, Villani L, Finotto S, Ammatuna E, Alterini R, Carrai V, Capaccioli G, Di Lollo S, Liso V, Rambaldi A, Bosi A, Barbui T (2008) Characteristics and clinical correlates of MPL $515 \mathrm{~W}>\mathrm{L} / \mathrm{K}$ mutation in essential thrombocythemia. Blood 112(3):844-847. https:// doi.org/10.1182/blood-2008-01-135897

11. Sideri S, Papageorgiou SN, Eliades T (2018) Registration in the international prospective register of systematic reviews (PROSPERO) of systematic review protocols was associated with increased review quality. J Clin Epidemiol 100:103-110. https:// doi.org/10.1016/j.jclinepi.2018.01.003

12. Murphy S, Peterson P, Iland H, Laszlo J (1997) Experience of the Polycythemia Vera Study Group with essential thrombocythemia: a final report on diagnostic criteria, survival, and leukemic transition by treatment. Semin Hematol 34(1):29-39

13. Vardiman JW, Harris NL, Brunning RD (2002) The World Health Organization (WHO) classification of the myeloid neoplasms. Blood 100(7):2292-2302. https://doi.org/10.1182/ blood-2002-04-1199

14. Tefferi A, Vardiman JW (2008) Classification and diagnosis of myeloproliferative neoplasms: the 2008 World Health Organization criteria and point-of-care diagnostic algorithms. Leukemia 22(1):14-22. https://doi.org/10.1038/sj.leu.2404955

15. Hozo SP, Djulbegovic B, Hozo I (2005) Estimating the mean and variance from the median, range, and the size of a sample. BMC Med Res Methodol 5:13. https://doi.org/10.1186/1471-2288-5-13

16. GA Wells BS, D O'Connell, J Peterson, V Welch, M Losos, P Tugwell The Newcastle-Ottawa Scale (NOS) for assessing the quality of nonrandomised studies in meta-analyses. http://www. ohri.ca/programs/clinical_epidemiology/oxford.asp

17. Andrade C (2015) Understanding relative risk, odds ratio, and related terms: as simple as it can get. J Clin Psychiatry 76(7):e857861. https://doi.org/10.4088/JCP.15f10150

18. Zhang J, Yu KF (1998) What's the relative risk? A method of correcting the odds ratio in cohort studies of common outcomes. JAMA 280(19):1690-1691. https://doi.org/10.1001/jama.280.19. 1690

19. Andrade C (2020) Mean difference, standardized mean difference (SMD), and their use in meta-analysis: as simple as it gets. J Clin Psychiatry 81(5). https://doi.org/10.4088/JCP.20f13681 
20. Egger M, Davey Smith G, Schneider M, Minder C (1997) Bias in meta-analysis detected by a simple, graphical test. BMJ 315(7109):629-634. https://doi.org/10.1136/bmj.315.7109.629

21. Begg CB, Mazumdar M (1994) Operating characteristics of a rank correlation test for publication bias. Biometrics 50(4):1088-1101

22. Dalton JE, Bolen SD, Mascha EJ (2016) Publication bias: the elephant in the review. Anesth Analg 123(4):812-813. https://doi.org/ 10.1213/ane.0000000000001596

23. Beer PA, Campbell PJ, Scott LM, Bench AJ, Erber WN, Bareford D, Wilkins BS, Reilly JT, Hasselbalch HC, Bowman R, Wheatley K, Buck G, Harrison CN, Green AR (2008) MPL mutations in myeloproliferative disorders: analysis of the PT-1 cohort. Blood 112(1):141-149. https://doi.org/10.1182/blood-2008-01-131664

24. Fu R, Xuan M, Sun T, Bai J, Cao Z, Zhang L, Yang R, Zhang L (2014) Analysis of calreticulin mutations in Chinese patients with essential thrombocythemia: clinical implications in diagnosis, prognosis and treatment. J Thromb Haemost 12:43-44. https://doi.org/ 10.1111/jth.12618/abstract

25. Tefferi A, Wassie EA, Guglielmelli P, Gangat N, Belachew AA, Lasho TL, Finke C, Ketterling RP, Hanson CA, Pardanani A, Wolanskyj AP, Maffioli M, Casalone R, Pacilli A, Vannucchi AM, Passamonti F (2014) Type 1 versus type 2 calreticulin mutations in essential thrombocythemia: a collaborative study of 1027 patients. Am J Hematol 89(8):E121-124. https://doi.org/10.1002/ajh.23743

26. Alvarez-Larrán A, Angona A, Andrade-Campos M, Soledad Noya M, Teresa Gómez-Casares M, Cuevas B, Caballero G, GarcíaHernández C, García-Gutiérrez V, Palomino A, Ferrer-Marín F, Isabel Mata-Vázquez M, Moretó A, Magro E, Murillo I, Manuel Alonso-Domínguez J, María Guerra J, Guerrero L, María Raya J, Pérez-Encinas M, Carreño-Tarragona G, Fox L, Pastor-Galán I, Bellosillo B, Carlos Hernández-Boluda J (2020) Cytoreductive treatment in patients with CALR-mutated essential thrombocythaemia: a study comparing indications and efficacy among genotypes from the Spanish Registry of Essential Thrombocythaemia. Br J Haematol.https://doi.org/10.1111/bjh.16988

27. Li MY, Chao HY, Sun AN, Qiu HY, Jin ZM, Tang XW, Han Y, Fu CC, Chen SN, Wu DP (2017) Clinical significance of JAK2 、 CALR and MPL gene mutations in 1648 Philadelphia chromosome negative myeloproliferative neoplasms patients from a single center. Zhonghua xue ye xue za zhi $=$ Zhonghua xueyexue zazhi 38(4):295-300. https://doi.org/10.3760/cma.j.issn.0253-2727.2017. 04.007

28. Prejzner W, Mital A, Bieniaszewska M, Leszczyńska A, Szymańska A, Czarnogórski M, Hellmann A (2020) Clinical characteristics of essential thrombocythemia patients depend on the mutation status. Acta Haematol Pol 51(4):230-235. https://doi.org/10.2478/ ahp-2020-0040

29. Julian Higgins JT, Jacqueline Chandler, Miranda Cumpston, Tianjing Li, Matthew Page, Vivian Welch Chapter 10: analysing data and undertaking meta-analyses. Cochrane Handbook for Systematic Reviews of Interventions 6.2

30. Hultcrantz M, Wilkes SR, Kristinsson SY, Andersson TM, Derolf ÅR, Eloranta S, Samuelsson J, Landgren O, Dickman PW, Lambert PC, Björkholm M (2015) Risk and cause of death in patients diagnosed with myeloproliferative neoplasms in sweden between 1973 and 2005: a population-based study. J Clin Oncol 33(20):22882295. https://doi.org/10.1200/jco.2014.57.6652

31. Al Assaf C, Van Obbergh F, Billiet J, Lierman E, Devos T, Graux C, Hervent AS, Emmerechts J, Tousseyn T, De Paepe P, Papadopoulos P, Michaux L, Vandenberghe P (2015) Analysis of phenotype and outcome in essential thrombocythemia with CALR or JAK2 mutations. Haematologica 100(7):893-897. https://doi.org/10.3324/ haematol.2014.118299

32. Tefferi A, Wassie EA, Lasho TL, Finke C, Belachew AA, Ketterling RP, Hanson CA, Pardanani A, Gangat N, Wolanskyj AP (2014) Calreticulin mutations and long-term survival in essential thrombocythemia. Leukemia 28(12):2300-2303. https://doi.org/10. 1038/leu.2014.148

33. Qin Y, Wang X, Zhao C, Wang C, Yang Y (2015) The impact of JAK2 $2617 \mathrm{~F}$ mutation on different types of thrombosis risk in patients with essential thrombocythemia: a meta-analysis. Int J Hematol 102(2):170-180. https://doi.org/10.1007/ s12185-015-1808-y

34. Elala YC, Lasho TL, Gangat N, Finke C, Barraco D, Haider M, Abou Hussein AK, Hanson CA, Ketterling RP, Pardanani A, Tefferi A (2016) Calreticulin variant stratified driver mutational status and prognosis in essential thrombocythemia. Am J Hematol 91(5):503506. https://doi.org/10.1002/ajh.24338

35. Tefferi A, Guglielmelli P, Larson DR, Finke C, Wassie EA, Pieri L, Gangat N, Fjerza R, Belachew AA, Lasho TL, Ketterling RP, Hanson CA, Rambaldi A, Finazzi G, Thiele J, Barbui T, Pardanani A, Vannucchi AM (2014) Long-term survival and blast transformation in molecularly annotated essential thrombocythemia, polycythemia vera, and myelofibrosis. Blood 124(16):2507-2513. https://doi.org/ 10.1182/blood-2014-05-579136

36. Alvarez-Larran A, Martínez D, Arenillas L, Rubio A, ArellanoRodrigo E, Boluda JCH, Papaleo N, Caballero G, Martínez C, Ferrer-Marín F, Mata MI, Pérez-Encinas M, Durán MA, Alonso JM, Carreño-Tarragona G, Alonso JM, Noya S, Magro E, Pérez R, López-Guerra M, Pastor-Galán I, Cervantes F, Besses C, Colomo L, Rozman M (2018) Essential thrombocythaemia with mutation in MPL: Clinicopathological correlation and comparison with JAK 2V617F-mutated and CALR-mutated genotypes. J Clin Pathol 71(11):975-980. https://doi.org/10.1136/jclinpath-2018-205227

37. Barbui T, Finazzi G, Carobbio A, Thiele J, Passamonti F, Rumi E, Ruggeri M, Rodeghiero F, Randi ML, Bertozzi I, Gisslinger H, Buxhofer-Ausch V, De Stefano V, Betti S, Rambaldi A, Vannucchi AM, Tefferi A (2012) Development and validation of an International Prognostic Score of thrombosis in World Health Organization-essential thrombocythemia (IPSET-thrombosis). Blood 120(26):51285133; quiz 5252. https://doi.org/10.1182/blood-2012-07-444067

38. Barbui T, Vannucchi AM, Buxhofer-Ausch V, De Stefano V, Betti S, Rambaldi A, Rumi E, Ruggeri M, Rodeghiero F, Randi ML, Bertozzi I, Gisslinger H, Finazzi G, Carobbio A, Thiele J, Passamonti F, Falcone C, Tefferi A (2015) Practice-relevant revision of IPSETthrombosis based on 1019 patients with WHO-defined essential thrombocythemia. Blood Cancer J 5(11):e369. https://doi.org/10. 1038/bcj.2015.94

39. Haider M, Gangat N, Lasho T, Abou Hussein AK, Elala YC, Hanson C, Tefferi A (2016) Validation of the revised International Prognostic Score of Thrombosis for Essential Thrombocythemia (IPSET-thrombosis) in 585 Mayo Clinic patients. Am J Hematol 91(4):390-394. https://doi.org/10.1002/ajh.24293

40. Passamonti F, Thiele J, Girodon F, Rumi E, Carobbio A, Gisslinger H, Kvasnicka HM, Ruggeri M, Randi ML, Gangat N, Vannucchi AM, Gianatti A, Gisslinger B, Müllauer L, Rodeghiero F, d'Amore ES, Bertozzi I, Hanson CA, Boveri E, Marino F, Maffioli M, Caramazza D, Antonioli E, Carrai V, Buxhofer-Ausch V, Pascutto C, Cazzola M, Barbui T, Tefferi A (2012) A prognostic model to predict survival in 867 World Health Organization-defined essential thrombocythemia at diagnosis: a study by the International Working Group on Myelofibrosis Research and Treatment. Blood 120(6):1197-1201. https://doi.org/10.1182/blood-2012-01-403279

41. Szuber N, Hanson CA, Lasho TL, Finke C, Ketterling RP, Pardanani A, Gangat N, Tefferi A (2018) MPL-mutated essential thrombocythemia: a morphologic reappraisal. Blood Cancer J 8(12):121. https://doi.org/10.1038/s41408-018-0159-3

Publisher's note Springer Nature remains neutral with regard to jurisdictional claims in published maps and institutional affiliations. 